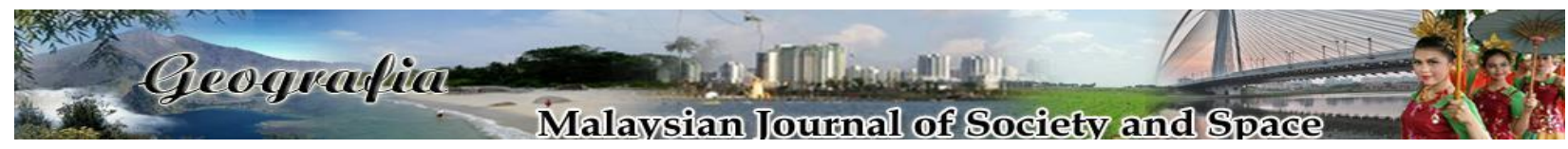

\title{
Impak media sosial terhadap gangguan seksual atas talian dalam kalangan wanita muda
}

\author{
Norhayati Mat Ghani, Suriati Ghazali \\ Bahagian Geografi, Pusat Pengajian Ilmu Kemanusiaan \\ Universiti Sains Malaysia
}

Correspondence: Suriati Ghazali (email: suriati@usm.my)

Received: 04 March 2021; Accepted: 24 May 2021; Published: 27 August 2021

\begin{abstract}
Abstrak
Penggunaan media sosial yang sangat popular pada era mutakhir ini turut membawa kepada kejadian gangguan atas talian terhadap sebilangan kumpulan masyarakat yang mudah menjadi mangsa, seperti golongan wanita muda. Antara gangguan atas talian yang kerap berlaku ke atas wanita muda ialah gangguan seksual, buli siber, ugut siber, fitnah, maki hamun, dan dimalukan. Pihak Siber Sekuriti Malaysia melaporkan sebanyak 499 kes gangguan atas talian telah berlaku pada tahun 2020, dan gangguan seksual adalah salah satu daripadanya. Objektif kajian ini adalah untuk membincangkan tentang impak penggunaan media sosial terhadap gangguan seksual atas talian dalam kalangan wanita muda di Pulau Pinang, Malaysia. Kajian ini menggunakan kaedah kualitatif dalam pengumpulan data dan perbincangan. Seramai tujuh orang wanita muda yang pernah menjadi mangsa gangguan seksual atas talian dipilih sebagai informan untuk ditemu bual secara mendalam. Informan dipilih menggunakan kaedah persampelan secara bertujuan dan bola salji. Kajian mendapati penggunaan media sosial mendedahkan mereka kepada gangguan seksual atas talian, seperti menerima pesanan lucah dan gambar lucah, diajak bercerita tentang seks, dan diajak untuk melakukan hubungan seks. Dapatan kajian menunjukkan bahawa, wanita muda mudah menjadi mangsa gangguan seksual atas talian kerana kecanggihan aplikasi media sosial itu sendiri, antaranya, kebolehan mengesan lokasi pengguna lain. Selain itu, sikap dan tujuan penjenayah siber yang menyasarkan golongan wanita muda sebagai mangsa, dan sikap wanita muda yang mudah memuat-naik maklumat peribadi di media sosial, berpotensi menyebabkan mereka disasarkan untuk menjadi mangsa. Kajian ini menyumbang kepada pengetahuan tentang faktor dan potensi gangguan seksual yang dialami oleh pengguna media sosial dalam kalangan wanita muda. Kajian ini boleh dijadikan landasan untuk mengelakkan potensi-potensi tersebut. Di samping itu, kajian ini dapat mengembangkan lagi skop kajian geografi sosial-jenayah dengan melibatkan media sosial masa kini.
\end{abstract}

Kata kunci: Gangguan seksual atas talian, kerentanan, mangsa, media sosial, wanita muda 


\title{
The impact of social media on online social harassment among young women
}

\begin{abstract}
The use of social media, which is very popular in this modern era, has also led to the incidence of online harassment against a number of vulnerable groups of society, such as young women. Among the most common online harassment towards young women are sexual harassment, cyberbullying, defamation, name-calling, and humiliation. Cyber Securities Malaysia reported a total of 499 cases of online harassment occurred in 2020, and sexual harassment was one of them. The objective of this study was to discuss the impact of social media usage towards online sexual harassment among young women in Penang. This study uses qualitative methods for data collection and discussion. A total of seven young women who had been victims of online sexual harassment were selected for in-depth interviews. Informants were selected using purposive and snowball sampling methods. This study has found that the use of social media exposes them to online sexual harassment, such as receiving pornographic messages and pictures, being coerced to talk about sex, and being harrassed into having sex. The findings of the study also show that young women can easily become victims of online sexual harassment due to the sophistication of the social media application itself, among others, the ability to track the location of these women via social media. In addition, the attitudes and intentions of cybercriminals who target young women as victims, and the attitudes of young women who easily upload personal information on social media, causes them to be targeted as victims. This study contributes knowledge on the factors and potential sexual harassment that may be experienced by social media users who are young women, and in turn can be used as a platform to avoid such potentials. In addition, this study can further expand the scope of the geography of crime by involving the social media environment of today.
\end{abstract}

Keywords: online sexual harassment, vulnerability, victims, social media, young women

\section{Pengenalan}

Media sosial merupakan saluran yang membolehkan masyarakat berbual, berkongsi pengetahuan, video, gambar, bersosialisasi, menerima maklumat dan menyebarkan maklumat secara interaktif (Boone, 2011; Jain, Gupta \& Anand 2012; Suriati et al., 2012; Thelwall, Sud \& Vis, 2012). Kepelbagaian fungsi media sosial telah menarik pelbagai lapisan masyarakat untuk menggunakan media baharu ini. Namun begitu, di sebalik keseronokan melayari media sosial ini, wujud cabaran dan masalah sehingga pengguna terdedah kepada persekitaran jenayah siber. Golongan wanita juga merupakan pengguna media sosial aktif, mereka mudah dipengaruhi oleh media sosial dan dilihat lebih mendominasi penggunaan media sosial (Greenwood, Perrin \& Duggan, 2016; Madden \& Zickuhr, 2011).

Pembabitan dan keterujaan wanita muda terhadap media sosial telah menyebabkan mereka terdedah kepada risiko jenayah siber. Malahan, sejak akhir-akhir ini media massa banyak melaporkan perihal wanita menjadi mangsa jenayah siber antaranya ditipu semasa melakukan pembelian dalam talian, mangsa penggodaman, keldai dadah, menjadi mangsa rogol kenalan laman sosial, penipuan dalam talian, pencerobohan komputer, ketagih terhadap internet, risiko terdedah kepada bahan seksual, gangguan seksual dan buli siber (Jain, Gupta, \& Anand, 2012; 
Reed \& Angel, 2000; Guan \& Subrahmanyam, 2009). Gangguan seksual siber merupakan salah satu gangguan siber yang sering berlaku terhadap golongan wanita muda. Dengan kewujudan internet, aktiviti seks secara atas talian meningkat secara drastik (Wery \& Billieux, 2017; Shakti \& Dhanoa, 2011). Aktiviti seks siber melibatkan interaksi antara dua pengguna media sosial atau lebih dalam perbincangan seks secara atas talian yang disimulasikan untuk mendapatkan keseronokan seksual (Daneback et al., 2005). Jenayah seksual siber menjadi isu besar dalam kalangan masyarakat dan media sosial berperanan penting dalam menyebarkan budaya negatif ini. Tingkah laku seksual masih dianggap sebagai perbuatan taboo dalam masyarakat kerana rakyat di Malaysia yang masih berpegang kepada budaya timur (Danish Yusrie \& Mohammad Rahim, 2017). Oleh itu, kajian ini akan membincangkan dengan lebih mendalam berkaitan gangguan seksual siber yang berlaku terhadap golongan wanita muda. Kajian ini penting dilakukan kerana dapat memberi maklumat berkaitan perilaku gangguan seksual siber dan mengapa tindakan negatif ini berlaku. Di samping itu, di Malaysia masih kurang maklumat berkaitan jenayah seksual dilakukan secara mendalam terhadap mangsa.

\section{Jenayah seksual dan kaitannya dengan sosial media}

Teknologi telekomunikasi dan perhubungan masa kini menjadikan media sosial sebagai pemudah cara kepada masyarakat untuk berhubung. Namun begitu, kemajuan teknologi ini juga menjadi antara punca jenayah seksual siber tersebar dalam kalangan masyarakat khususnya kepada golongan muda. Media sosial menjadi tempat kepada penjenayah untuk mencari, memerangkap dan mengajak mangsa ke arah perilaku seksual (Khadijah et al., 2012). Jenayah seksual yang berlaku kepada golongan wanita muda juga menjadi semakin rumit dan sukar untuk diatasi dengan adanya media sosial (Loizou, 2012). Banyak laporan berkaitan kesalahan seksual siber telah dilaporkan sehingga kegiatan tersebut telah menjadi fenomena biasa. Penjenayah seksual siber menjadikan pengguna media sosial sebagai mangsa mereka seperti menggalakkan seseorang bercakap perihal seks, melakukan sesuatu tindakan berbentuk gangguan seksual dan berkongsi maklumat peribadi seksual walaupun dengan orang yang tidak dikenali (Yar, 2012). Perlakuan mengajak orang lain ke arah tindakan seksual adalah bertentangan dengan cara hidup orang timur khususnya orang Melayu yang berteraskan nilai-nilai moral daripada ajaran agama Islam (Ab. Halim \& Zarin, 2009).

Golongan wanita dilihat lebih cenderung untuk menjadi mangsa gangguan seksual secara atas talian melalui aktiviti memuat naik gambar ke akaun laman sosial mereka (Fairbairn, 2013). Kajian oleh Pew Research Center dan American Life Project mendapati golongan wanita lebih celik media sosial berbanding golongan lelaki. Kumpulan pengkaji ini mendapati tingkah laku golongan wanita lebih mudah untuk berkongsi seperti berkongsi perasaan, gambar, video dan sebagainya secara atas talian. Hal ini menunjukkan bahawa, golongan wanita lebih bersikap terbuka semasa berinteraksi dalam talian (Maznah, 2014). Penglibatan golongan yang mudah rentan dalam rangkaian media sosial menimbulkan kebimbangan kerana persekitaran dalam talian berpotensi memberi ancaman seksual terutamanya kepada golongan kanak-kanak, remaja bawah umur dan wanita (Wolak et al., 2006). Dengan adanya media sosial, pengantunan seksual atau sexual grooming terhadap golongan muda semakin mudah dilakukan. Wujud istilah pedofilia (pedophilia) yang bermaksud pedo iaitu kanak-kanak dan filia iaitu 'cinta, suka', merujuk kepada kesukaan atau kecintaan orang dewasa kepada kanak-kanak, yang membawa kepada perlakuan seksual oleh orang dewasa terhadap golongan kanak-kanak (Amran Hassan \& Suriati Ghazali, 
2013). Selain itu, kehadiran media sosial telah merancakkan lagi pembabitan aktiviti golongan ini. Menurut Yar (2006), golongan pedofilia menjadikan rangkaian media sosial sebagai tempat untuk mereka memburu mangsa dengan cara mengenal pasti dan menghubungi mangsa melalui media sosial. Penjenayah seks akan menghubungi mangsa dan cuba mewujudkan hubungan. Apabila telah wujud kepercayaan dan keintiman antara mereka, pelaku akan cuba bersemuka dan mengajak mangsa untuk melakukan hubungan seks (Yar, 2006; Wolak et al., 2006). Golongan muda dijadikan sebagai alat pemuas nafsu di alam maya, iaitu dikenali sebagai seks siber. Seks siber merupakan aktiviti seks yang dilakukan tanpa bersemuka atau bersentuhan, tetapi dilakukan secara atas talian, antaranya melalui perbuatan seperti menggambarkan, membunyikan, dan berfantasi, yang mana semuanya berkisar tentang perlakuan seksual. Bagi merangsang kegiatan fantasi seks, pengguna media sosial biasanya memberi atau menyiarkan gambar mereka dalam bentuk yang erotik seperti dalam keadaan tidak berpakaian, sebahagian badan terdedah, atau menyiarkan gambar alat sulit mereka seperti payudara, faraj dan zakar (Young, 2000).

Gangguan seks siber berlaku apabila pengguna internet menunjukkan minat terhadap aktiviti seksual dan mengumpan pengguna lain untuk turut sama terlibat dengan aktiviti berkenaan. Golongan muda lebih cenderung untuk diumpan menjadi mangsa gangguan seksual atas talian. Kebanyakan mangsa adalah dalam golongan hampir sebaya dengan pemangsa, yang dikenali melalui media sosial (Collins, Martino, \& Shaw, 2011). Terdapat juga pengguna media sosial yang menerima gambar lucah, atau dipaksa untuk menghantar gambar lucah kepada pasangan mereka; dan lebih teruk lagi apabila terdapat ajakan untuk mengadakan hubungan seks melalui talian (Wolak et al., 2006; Collins, Martino, \& Shaw 2011). Selain itu, aplikasi dalam media sosial seperti WeChat juga menjadi salah satu platform yang boleh mendedahkan wanita muda ke dalam persekitaran jenayah siber. Sebagai contohnya, aplikasi dalam WeChat membolehkan pengguna untuk mengesan pengguna lain dalam lingkungan jarak 20 kilometer, dengan hanya menekan butang carian berdekatan (search nearby). Dengan cara itu, pengguna mampu mengakses sesiapa sahaja di sekeliling mereka yang menggunakan aplikasi sama (Xiao, 2018). Aplikasi dalam media sosial ini menjadi antara faktor yang menyebabkan wanita muda menjadi mangsa gangguan seksual siber. Sehubungan dengan itu, kajian ini akan mengkaji secara lebih mendalam tentang gangguan seksual yang dialami oleh wanita muda semasa mereka menggunakan media sosial.

\section{Metodologi}

Kajian ini menggunakan pendekatan induktif bagi proses pengumpulan dan penafsiran data. Pengkaji memilih tujuh (7) orang informan dari kalangan wanita muda dari Pulau Pinang, yang berusia antara 18 hingga 29 tahun. Kategori umur ini dipilih kerana mengambil kira pengguna dalam lingkungan umur yang aktif menggunakan media sosial (Lenhart et al., 2010, Maznah, 2014; Nielsen, 2011). Pew Research Center (2015) menjelaskan bahawa separuh daripada pengguna telefon pintar terdiri daripada golongan muda berusia antara 18 hingga 30 tahun. Pemilihan informan kajian dilakukan melalui kaedah persampelan bertujuan bagi membolehkan pengkaji memilih informan yang menepati kriteria diingini (Othman, 2013; Colonius, 2006). Kriteria informan yang ditetapkan ialah, mereka terdiri daripada wanita muda berumur antara 18 hingga 29 tahun, mempunyai akaun media sosial, mengakses media sosial mereka setiap hari, dan pernah menerima gangguan seks atas talian.. Kajian ini juga menggunakan kaedah persampelan bola salji, iaitu menggunakan saranan daripada informan pertama untuk mendapatkan informan yang seterusnya (Suriati et al., 2012). Pengkaji telah mendapat kerjasama daripada seorang pemberi 
maklumat utama, yang telah memperkenalkan pengkaji kepada informan berikutnya, yang turut mempunyai maklumat atau pengalaman sebagai mangsa jenayah seksual atas talian. Pengalaman jenayah siber terhadap kenalan terdekat dapat memperkayakan lagi hasil dapatan kajian dan memberi maklumat tambahan tentang senario jenayah siber yang berlaku terhadap wanita muda di Pulau Pinang. Kajian ini merupakan kajian bersifat kualitatif, oleh itu pengkaji hanya memilih tujuh (7) orang informan untuk ditemubual secara mendalam tentang jenayah yang dialami. Justifikasi pemilihan hanya tujuh orang informan adalah releven bagi kajian bersifat fenomena, yang mana Creswell (1998) mencadangkan lima hingga 25 orang responden ditemu bual adalah memadai, manakala Morse (1994) mencadangkan sekurang-kurangnya enam orang responden adalah memadai. Hasil temubual mendalam dianalisis dan ditafsirkan melalui teknik interpretasi, refleksi dan analisis kandungan. Seterusnya data dipetik untuk memaparkan tentang aspek yang dibincangkan, iaitu tentang gangguan seksual dalam kalangan wanita muda berdasarkan sudut pandangan pemberi maklumat (informan). Etika penyelidikan yang diamalkan ialah, keizinan responden didapatkan terlebih dahulu sebelum mereka ditemubual, dan maklumat diri responden dirahsiakan dengan tidak memaparkan nama dan identiti sebenar mereka (Norhayati \& Suriati, 2016). Kajian ini menggantikan nama sebenar responden dengan gelaran informan seperti Informan 1, Informan 2, Informan 3 dan seterusnya untuk melindungi maklumat peribadi informan. Informan juga diyakinkan bahawa maklumat yang diberikan tidak disebarkan kepada umum dan ianya hanya digunakan untuk tujuan penyelidikan sahaja.

\section{Hasil kajian dan perbincangan}

\section{Profil informan kajian}

Jadual 1 menunjukkan profil tujuh (7) orang informan yang ditemu bual secara mendalam berkaitan gangguan seksual yang dialami mereka ketika menggunakan media sosial. Informan yang ditemu bual terdiri daripada pelbagai status sosial seperti pelajar, suri rumah, pegawai khidmat pelanggan, bekerja sendiri, juru jual dan masih mencari pekerjaan. Mereka juga mempunyai tahap pendidikan yang berbeza seperti di peringkat Sijil Pelajaran Malaysia, Sijil dan Ijazah Sarjana Muda. Kesemua informan menunjukkan mereka menggunakan lebih daripada satu akaun media sosial. Facebook dan WhatsApp pula merupakan media sosial paling popular di kalangan informan, di mana kesemua informan ditemui menggunakan kedua-dua aplikasi ini. Jadual 1 juga menunjukkan jenis-jenis gangguan seksual yang dialami oleh informan.

Jadual 1: Profil informan yang ditemu bual secara mendalam.

\begin{tabular}{|c|c|c|c|c|}
\hline Informal & $\begin{array}{c}\text { Status sosio } \\
\text { ekonomi }\end{array}$ & Pendidikan & $\begin{array}{c}\text { Media sosial } \\
\text { yang digunakan }\end{array}$ & Gangguan seksual yang dialami \\
\hline $\begin{array}{l}\text { Informan } 1, \\
21 \text { tahun }\end{array}$ & Pelajar & Sijil & $\begin{array}{l}\text { Facebook, } \\
\text { WhatsApp, } \\
\text { Instagram, } \\
\text { WeChat }\end{array}$ & $\begin{array}{l}\text { Menerima mesej/gambar lucah beberapa } \\
\text { kali daripada individu tidak dikenali semasa } \\
\text { menggunakan media sosial }\end{array}$ \\
\hline $\begin{array}{l}\text { Informan } 2, \\
24 \text { tahun }\end{array}$ & Suri rumah & SPM & $\begin{array}{l}\text { Facebook, } \\
\text { WhatsApp, } \\
\text { WeChat }\end{array}$ & Menerima mesej/gambar lucah \\
\hline
\end{tabular}




\begin{tabular}{|c|c|c|c|c|}
\hline $\begin{array}{l}\text { Informan } 3, \\
28 \text { tahun }\end{array}$ & $\begin{array}{l}\text { Pegawai } \\
\text { khidmat } \\
\text { pelanggan }\end{array}$ & Sijil & $\begin{array}{l}\text { Facebook, } \\
\text { WhatsApp, } \\
\text { Instagram, } \\
\text { Telegram, } \\
\text { Pinterest }\end{array}$ & $\begin{array}{l}\text { Menerima mesej/gambar lucah } \\
\text { Adik sepupu terlibat dengan aktiviti seksual } \\
\text { selepas berkenalan dengan lelaki di } \\
\text { Facebook, menyebabkan responden berasa } \\
\text { bimnang dan terganggu }\end{array}$ \\
\hline $\begin{array}{l}\text { Informan } 4, \\
24 \text { tahun }\end{array}$ & Bekerja sendiri & $\begin{array}{l}\text { Ijazah Sarjana } \\
\text { Muda }\end{array}$ & $\begin{array}{l}\text { Facebook, } \\
\text { WhatsApp, } \\
\text { WeChat }\end{array}$ & $\begin{array}{l}\text { Menerima mesej/gambar lucah } \\
\text { Diajak bercerita tentang perkara lucah }\end{array}$ \\
\hline $\begin{array}{l}\text { Informan } \\
29 \text { tahun }\end{array}$ & Bekerja sendiri & $\begin{array}{l}\text { Ijazah Sarjana } \\
\text { Muda }\end{array}$ & $\begin{array}{l}\text { Facebook, } \\
\text { WhatsApp, } \\
\text { WeChat }\end{array}$ & $\begin{array}{l}\text { Menerima mesej/gambar lucah } \\
\text { Rakan lelaki yang dikenali mengajak untuk } \\
\text { bercerita tentang perkara lucah ketika } \\
\text { menggunakan media sosial } \\
\text { Adik menjadi mangsa eksploitasi seksual } \\
\text { oleh pengguna lebih dewasa (diajak } \\
\text { bercerita tentang perkara berkaitan seks) }\end{array}$ \\
\hline $\begin{array}{l}\text { Informan } 6 \\
22 \text { tahun }\end{array}$ & Juru jual & SPM & $\begin{array}{l}\text { Facebook, } \\
\text { WhatsApp, } \\
\text { Instagram, } \\
\text { WeChat, Twitter, } \\
\text { MySpace }\end{array}$ & $\begin{array}{l}\text { Menerima mesej/gambar lucah } \\
\text { Diajak bercerita tentang perkara lucah } \\
\text { Diajak melakukan hubungan seks }\end{array}$ \\
\hline $\begin{array}{l}\text { Informan } 7 \\
25 \text { tahun }\end{array}$ & $\begin{array}{l}\text { Menganggur } \\
\text { dan sedang } \\
\text { mencari } \\
\text { pekerjaan }\end{array}$ & SPM & $\begin{array}{l}\text { Facebook, } \\
\text { WhatsApp, } \\
\text { WeChat }\end{array}$ & Menerima mesej lucah/gambar lucah \\
\hline
\end{tabular}

\section{Jenis gangguan seksual yang dialami}

Berdasarkan temubual yang dijalankan ke atas responden, penulis merumuskan bahawa gangguan seksual yang dialami oleh informan berlaku dalam tiga keadaan, iaitu, (1) menerima pesanan dan gambar lucah, (2) diajak bercerita tentang seks dan (3) diajak melakukan hubungan seks. Kajian mendapati bahawa, kesemua tujuh orang informan mengakui mereka pernah menerima pesanan atau gambar berbentuk lucah ketika menggunakan media sosial. Manakala, seramai tiga orang informan pula menyatakan mereka pernah diajak untuk bercerita tentang perkara berbentuk seks. Di samping itu, seorang informan dan dua orang kenalan terdekat mereka pernah diajak untuk melakukan hubungan seks ketika sedang dalam talian (Jadual 2). Keadaan ini bertepatan dengan kajian Wolak et al. (2006) dan Yar (2012) yang menjelaskan bahawa, penjenayah siber menjadikan pengguna media sosial sebagai mangsa seks seperti menggalakkan seseorang bercakap perihal seks, melakukan sesuatu berbentuk seksual dan berkongsi maklumat peribadi berbentuk seksual, walaupun dengan orang yang tidak dikenali.

Jadual 2: Kategori gangguan seksual.

\begin{tabular}{lc} 
Kategori gangguan seksual & Kekerapan kes \\
\hline Menerima pesanan dan gambar lucah & 7 \\
Diajak bercerita tentang seks & 3 \\
Diajak melakukan hubungan seks $\quad$ Jumlah & 3 \\
& 13 \\
\hline
\end{tabular}

Nota: Jumlah gangguan seksual yang dipaparkan adalah berbeza dengan jumlah informan yang menjadi mangsa. Ini kerana, terdapat informan yang mengalami beberapa jenis gangguan seksual, seperti menerima pesanan lucah dan diajak bercerita tentang perkara lucah. 


\section{Menerima pesanan dan gambar lucah dalam talian}

Bahagian ini membincangkan tentang pengalaman informan menjadi mangsa gangguan seksual melalui penerimaan pesanan dan imej lucah daripada pengguna lain. Menurut informan-informan ini, penghantar pesanan dan gambar lucah datang daripada individu-individu yang dikenali dan juga individu-individu yang tidak dikenali oleh mereka. Informan 1 menceritakan, bentuk gangguan seksual yang dialami olehnya ialah menerima pesanan dan imej lucah. Informan 1 menceritakan pengalamannya menerima gambar lucah daripada individu yang tidak dikenali melalui aplikasi WeChat. Menurut beliau:

“...semasa saya sedang online, ada seorang lelaki hantar gambar lucah kepada saya. Saya terkejut, tetapi masa tu saya fikir dia tersilap hantar mesej. Kali kedua saya online, sekali lagi dia hantar gambar lucah. Gambar pada profilnya juga ditukar kepada gambar lucah. Saya takut sangat....saya block (halang) dia dan off search nearby (tutup pencarian) di WeChat" (Informan 1, 21 tahun).

Sorotan kajian lepas menunjukkan bahawa, aplikasi WeChat mampu diakses oleh sesiapa sahaja di sekeliling mereka yang menggunakan aplikasi sama. Dengan hanya membuka carian orang berdekatan (search nearby), pengguna lain boleh dikesan dalam lingkungan jarak $20 \mathrm{~km}$ (Xiao, 2018). Pengguna juga boleh berkomunikasi dengan mereka yang mempunyai aplikasi sama walaupun tidak mengenali mangsa dan tidak mengetahui nombor telefon mereka.

Pengalaman dialami Informan $1 \mathrm{di}$ atas menunjukkan aplikasi dalam WeChat telah menggalakkan orang yang tidak dikenali untuk mengesan pengguna lain. Informan 1 menyatakan beliau menjadi mangsa gangguan seksual, yang mana pengguna lain menghantar gambar lucah kepadanya berulang kali melalui aplikasi WeChat. Akibat berasa rasa takut dan terganggu, informan bertindak menghalang (block) pengguna tersebut dan menutup aplikasi search nearby untuk tujuan keselamatan, serta menghalang individu tersebut daripada terus menghantar gambar lucah kepadanya.

Selain itu, Informan 2 pula menceritakan pengalamannya menerima pesanan lucah daripada individu yang hanya dikenali di media sosial sahaja. Menurut informan, pada awal kemunculan media sosial, informan suka memuat naik gambar dan status di media sosial.Tingkah laku tersebut membuka peluang kepada rakan dalam talian untuk memberi tanda suka (like) dan meninggalkan komen di akaun informan. Aktiviti seperti memuat naik gambar dan status mendatangkan masalah kerana informan bukan sahaja menerima pesanan berbentuk positif, malah menerima pesanan lucah daripada pengguna lain. Menurut Informan 2:

“...semasa awal-awal ada media sosial saya suka add kawan-kawan walaupun saling tak kenal. Rasa seronok ada friend list ramai, pada masa itu tak fikir pun kesan buruknya. Saya banyak post gambar dan update status di Facebook. Setelah itu baru saya sedar, ada rakan yang saya tak kenal like gambar dan hantar mesej lucah kepada saya. Mereka mesej saya, kata 'awak cantik, badan seksi, saya suka tengok senyuman awak' dan macam-macam. Kalau dia tidak tengok bentuk badan dan fizikal saya kenapa dia mesej macam tu" (Informan 2, 20 tahun).

Dapatan kajian menemukan, tindakan seperti memuji bentuk tubuh badan dan mengajak berbicara perihal seks merupakan tindakan gangguan seksual secara terang-terangan. Menurut Zakaria et al. (2001) dalam Wilson (1995), gangguan seksual merupakan tindakan bukan lisan (paparan gambar, bersiul, pergerakan isyarat seksual dan lain-lain), fizikal (tidak semestinya 
sentuhan), lisan (penyataan dan percakapan berunsur seksual) dan intimidasi (komen lucah mengenai pakaian, rupa atau perbuatan). Hasil dapatan ini menyokong kajian Fairbairn (2013) yang menjelaskan bahawa golongan muda cenderung menjadi mangsa gangguan seksual melalui aktiviti memuat naik gambar ke akaun laman sosial mereka.

Pesanan dan gambar lucah turut dihantar melalui spam kepada pengguna media sosial. Mesej dari spam ditujukan kepada orang ramai secara rawak dan sesiapa sahaja boleh menerima pesanan tersebut, sama ada berbentuk positif atau pun negatif. Perkara ini diceritakan oleh Informan 3 (28 tahun), di mana beliau menyatakan bahawa beliau kerap menerima pesanan lucah melalui spam di Facebook. Dalam temu bual bersama informan, informan meluahkan kebimbangan sekiranya bahan lucah dikongsikan kepada kanak-kanak atau remaja di bawah umur. Menurut Salmah dan Malisah (2016), usia kanak-kanak yang masih belum matang, belum mampu membuat penilaian, serta tidak dapat membezakan realiti sebenar, boleh mendorong mereka untuk meniru sebarang aksi yang mereka tonton. Menurut Informan 3:

“...saya selalu dapat pesanan lucah dalam Facebook, biasanya daripada spam. Dia akan forward mesej yang sama kepada orang ramai. Saya risau juga, kalau orang dewasa dapat mesej ini mereka dapat fikir lagi, tapi kalau budak-budak atau yang bawah umur, macam mana kan...saya ni memang jenis tak layan kalau mesej spam" (Informan 3, 28 tahun).

Dapatan kajian menunjukkan bahawa media sosial menjadi punca kepada penyebaran bahan lucah dan tidak bermoral dalam kalangan pengguna media sosial. Perkongsian bahan lucah juga boleh mengundang masalah sekiranya penerima pesanan tersebut meniru aksi yang ditonton mereka. Daripada pemerhatian pengkaji, perilaku menghantar dan menerima pesanan dan imej berbentuk lucah bukan sahaja berpunca daripada sikap penjenayah siber, tetapi juga berpunca daripada sikap orang ramai iaitu pengguna media sosial sendiri. Informan menceritakan, perbuatan wanita muda memuat-naik gambar dan video dengan imej seksi, aksi ghairah dan mendedahkan aurat, telah mendorong pihak berlawanan jantina yang melihat aksi tersebut ke arah melakukan gangguan seksual dalam talian, seperti mendorong mereka meninggalkan komen berbaur lucah. Perkara ini dinyatakan oleh Informan 4. Informan 4 menceritakan bahawa rakannya pernah memuat naik gambar dan video dalam keadaan seksi di Facebooknya. Gambar dan video tersebut telah menarik perhatian lelaki untuk memberi komen lucah kepada rakannya. Menurutnya:

“...kawan saya sudah berkahwin, tapi suami dia tak pedulikan dia. Mungkin dia rasa kurang perhatian, jadi nak tarik perhatian orang ramai dia selalu post gambar dan video seksi di Facebook. Saya pernah tengok dia post gambar atas katil, pakai tudung tapi nampak lurah dada, dia juga buat video gesel kaki dan paha seperti menggoda. Ramai lelaki komen kata badan awak gebu, montok, putih melepak, seksi, menggoda dan banyak komen lucah dia terima. Selepas dapat mesej macam-macam, dia marah sebab kata dia kena gangguan seksual. Tapi saya rasa dia yang salah sebab muat naik gambar dan video macam tu" (Informan 4, 24 tahun).

Kajian mendapati bahawa, perkongsian gambar dalam keadaan berpakaian seksi dan video yang menampakkan bentuk fizikal telah menarik perhatian golongan lelaki untuk meninggalkan komen berbentuk lucah kepada golongan wanita. Gangguan seksual yang diterima berpunca daripada sikap wanita muda yang gemar memuat naik gambar dan video yang tidak sesuai di 
media sosial. Tindakan tersebut mendatangkan ancaman kepada mereka ketika menggunakan media sosial.

\section{Diajak bercerita tentang seks dalam talian}

Media sosial digunakan sebagai platform untuk meluahkan perasaan, mempamerkan identiti tersembunyi yang tidak berupaya dizahirkan dalam dunia nyata, dan menonjolkan diri tanpa risau halangan dan pandangan negatif masyarakat (Azianura Hani \& Mohammad Rahim, 2019). Oleh itu, melalui penggunaan media sosial, pengguna bebas untuk berbual dan bercerita tentang apa sahaja termasuk perkara bersifat atau berbau seks. Penemuan ini seperti yang diceritakan oleh Informan 5, yang mana beliau menyatakan telah menjadi mangsa gangguan seksual daripada individu yang dikenalinya. Dapatan ini menyokong kajian oleh Khadijah et al. (2012) yang menyatakan bahawa media sosial telah menjadi medium kepada penjenayah untuk memerangkap dan mengajak mangsa ke arah perilaku seksual. Informan 5 menjelaskan gangguan seksual berkenaan tidak berlaku ketika mereka berkomunikasi secara berhadapan, dan hanya berlaku ketika mereka berkomunikasi menggunakan media sosial sahaja. Penemuan ini membuktikan bahawa komunikasi dalam talian dapat merubah karakter dan tingkah laku pengguna ketika menggunakan media sosial. Menurut Informan 5:

“...saya pernah kenal seorang lelaki di tempat kerja. Kat tempat kerja dia pendiam dan senyum bila jumpa dengan saya. Kami ada mesej-mesej...awalnya lelaki ni macam biasa - tanya khabar, tanya buat apa, sudah makan ke? Tapi bila sudah kenal agak lama, dia makin pelik sebab asyik tanya pasal hal-hal sensitif. Mulanya saya rasa macam dia nak bergurau sebab di tempat kerja dia tidak banyak cakap tapi dalam WhatsApp dia mula cakap gatal dan lucah. Dia tanya saya pakai bra saiz berapa, sekarang pakai bra dan panties warna apa. Dia juga kata suka tengok buah dada saya. Saya rasa dia ni gila seks. Saya terus tak layan dan block nombor dia" (Informan 5, 29 tahun).

Dialog di atas menunjukkan kenalan informan tidak berasa malu untuk bercakap tentang perkara sensitif ketika menggunakan media sosial. Perilaku yang ditunjukkan oleh kenalan informan tersebut membuktikan bahawa, media sosial menyediakan medium yang boleh menggalakkan pengguna untuk bercakap tentang perkara lucah. Dapatan kajian ini disokong oleh Wolak et al. (2006) dan Yar (2012) yang menyatakan pelaku seksual siber (pelaku seksual atas talian) telah menjadikan pengguna media sosial sebagai mangsa seks, seperti menggalakkan seseorang untuk bercakap perkara berbaur seks dan lucah. Dalam satu kes lain, informan menceritakan seorang kenalan beliau telah menggalakkannya bercerita tentang perkara berbentuk sensitif dan berbau seks, iaitu dengan cara bertanyakan tentang warna coli dan seluar dalam yang dipakai oleh informan. Pertanyaan seperti itu membuka ruang ke arah perlakuan atau tindakan seksual atas talian, terutamanya jika diajukan kepada kanak-kanak dan remaja. Kanak-kanak dan remaja lebih cenderung untuk menjadi mangsa seks atas talian disebabkan usia mereka yang belum matang, di samping kecuaian dalam meneroka perkara baharu termasuk perkara berkaitan seks. Media sosial merupakan medium yang mudah mendedahkan golongan yang rentan (vulnerable) ini kepada bahan pornografi, gangguan seksual dan buli siber (Shakti \& Dhanoa, 2011). Hasil kajian ini menemui faktor kerentanan seks siber (vulnerability towards cybersex), dalam kata lain, kerentanan seks atas talian (vulnerability towards online sex) di kalangan wanita muda adalah disebabkan oleh penggunaan media sosial dalam usia yang masih muda. Perkara ini 
diceritakan oleh Informan 5, yang menyatakan adiknya yang masih bersekolah terlibat dengan perilaku negatif iaitu bercerita tentang seks dengan rakan lelakinya. Menurut informan :

“...saya pernah check (memeriksa) WhatsApp adik saya semasa dia tidur. Saya sangat terkejut sebab dia cerita perkara lucah dengan seorang lelaki yang mungkin boyfriend dia. Dalam perbualan di WhatsApp tu, mereka seolah-olah sedang buat hubungan seks. Saya malu nak sebut perkataan yang mereka gunakan, macam peluk, cium, sedap dan tut-tut (merujuk kepada kemaluan wanita dan lelaki). Saya terkejut baca WhatsApp dia orang dan tak sangka sebab adik saya pendiam, pemalu dan memang pelajar cemerlang di sekolah. Saya ada tanya kenapa mesej macam tu, dia kata saja suka-suka. Dia baru form 5 dan time tu dekat nak SPM, saya bagi nasihat sebab tak mahu dia stress" (Informan 5, 29 tahun).

Kenyataan Informan 5 menunjukkan perilaku berbentuk seksual boleh terjadi walaupun bukan melalui sentuhan atau tindakan fizikal. Menurut Daneback et al. (2005), seks siber merupakan interaksi antara dua orang atau lebih dalam perbincangan seks dalam talian yang disimulasikan untuk mendapatkan keseronokan seksual. Bagi merangsang kegiatan seks siber, pengguna berkenaan memberi atau menyiarkan gambar mereka dalam bentuk yang erotik seperti dalam keadaan tidak berpakaian, sebahagian badan terdedah, atau menyiarkan gambar seperti payudara, faraj dan zakar (Young, 2000). Seperti yang diceritakan oleh Informan 5, perlakuan adiknya merupakan tindakan imaginasi atau fantasi berkaitan perilaku seksual yang keterlaluan ketika menggunakan media sosial. Walaupun masih di bawah umur, adik Informan menunjukkan perilaku tidak sepatutnya dan keadaan tersebut berlaku melalui penggunaan media sosial tanpa pemantauan orang dewasa. Dapatan menunjukkan senario bercerita tentang perkara berkaitan seks amat dipengaruhi oleh aktiviti komunikasi yang berlaku dalam talian. Perilaku ini boleh menjadi 'barah' kepada pelaku kerana ketagihan seks siber memberikan kesan negatif terhadap diri pelaku dan orang sekeliling mereka (Young, 2000).

\section{Melakukan hubungan seks dalam talian}

Perkenalan di media sosial telah memudahkan penjenayah seksual untuk mencari dan meletakkan pengguna lain sebagai mangsa seks. Menurut Wolak et al. (2004) jenayah seksual atas talian biasanya dimulakan oleh lelaki dewasa yang menggunakan internet dan mereka menggunakan medium tersebut untuk bertemu, menggoda mangsa dan seterusnya mengajak mereka untuk melakukan hubungan seks. Penjenayah seksual menggunakan media sosial seperti Facebook, WeChat dan WhatsApp bagi membina hubungan dengan mangsa. Media sosial juga dijadikan sebagai katalog penjenayah seksual untuk memilih mangsa yang mereka inginkan. Selepas berjaya menjalinkan hubungan, pelaku mengajak mangsa untuk bersemuka dan melibatkan diri dalam aktiviti seksual secara jasmani (Wolak et al., 2004; Yar, 2006). Pada awal perkenalan, pelaku seksual tidak menunjukkan tindakan yang mencurigakan dan hanya bertanyakan soalan-soalan biasa. Namun, selepas berjaya menjalinkan dan mengukuhkan hubungan dengan bakal mangsa, pelaku menunjukkan kelakuan sebenar dengan cara menghantar pesanan lucah serta membuat panggilan video lucah kepada mangsa. Kajian ini disokong oleh Wolak et al. (2004) dan Yar (2006), yang mengatakan bahawa pada awal perkenalan, pelaku (atau pemangsa) seksual cuba membina hubungan dengan cara bertanyakan perkara-perkara biasa terhadap mangsa, dan pelaku berlagak normal. Apabila pelaku/pemangsa sudah berjaya membina hubungan dengan mangsa, pelaku cuba mengajak mangsa untuk melakukan hubungan seks dengannya. Kajian-kajian tersebut 
menepati kajian ini, yang mana Informan 6 menceritakan bahawa beliau menjadi mangsa ajakan untuk melakukan hubungan seksual oleh kenalan dalam Facebooknya. Menurut Informan 6: "...saya pernah dapat mesej lucah daripada kawan Facebook. Pada permulaan perkenalan dia sembang macam biasa dan tanya perkara-perkara biasa. Banyak kali kami chat, saya selesa dengan dia dan rasa dia baik. Tapi, lama-kelamaan dia macam berubah, dia ada hantar mesej ajak saya melakukan seks. Dia juga pernah video call saya beberapa kali. Semasa sedang video call dia tunjuk kemaluan dan bermain-main dengan kemaluan sendiri. Saya terkejut dan takut sangat, lepas tu, saya terus block dia" (Informan 6, 22 tahun).

Penemuan di atas menunjukkan bahawa, media sosial boleh mengubah sikap sebilangan masyarakat Timur yang sebelum ini menganggap perilaku seksual dan berbicara tentang seks sebagai perbuatan taboo dalam masyarakat (Danish Yusrie \& Mohammad Rahim, 2017). Dengan kewujudan media sosial, pelaku menjadi tidak sensitif dengan perbuatan tidak bermoral seperti menunjukkan kemaluan kepada pengguna lain ketika sedang berbual dalam talian. Perbuatan seperti ini bertentangan dengan cara hidup masyarakat Timur khususnya orang Melayu yang berteraskan nilai-nilai moral daripada ajaran agama Islam (Ab. Halim \& Zarin, 2009). Semasa ditemu bual, informan menyuarakan perasaan takut dan bimbang menjadi mangsa jenayah seksual sehingga beliau bertindak menyekat/block serta tidak lagi melayani individu berkenaan.

Sementara itu, Informan 7 pula menceritakan bahawa kenalannya diajak melakukan hubungan seksual oleh lelaki yang dikenali di media sosial. Terdapat pelaku seksual tanpa berselindung terus mengajak mangsa untuk melakukan hubungan seks. Kebiasaannya, pelaku seksual menggunakan akaun media sosial palsu untuk mencari mangsa (Noor Aziah, 2004), tetapi terdapat juga pengguna tanpa berselindung menggunakan akaun sebenar mereka bagi menarik perhatian golongan wanita muda untuk didekati. Informan 7 menceritakan:

"...kawan baik saya pernah berkenalan dengan lelaki di media sosial. Mereka tukartukar nombor telefon dan mula berhubungan melalui Whatsapp. Lelaki tu ajak kawan saya keluar dan kawan saya setuju. Malam sebelum mereka jumpa, dia mesej kawan saya nak ajak buat seks 'ringan-ringan' masa jumpa. Kawan saya terkejut, dia tanya saya bolehkah dia jumpa lelaki itu? Saya beri nasihat supaya tidak berjumpa, sebab saya takut dia diapa-apakan. Kawan saya mesej lelaki tu dan bagitau tak jadi jumpa, dia marah dan terus block kawan saya" (Informan 7, 24 tahun).

Perkara sama turut diceritakan oleh Informan 4 dengan menyatakan bahawa rakannya diajak melakukan hubungan seks dengan orang tidak dikenali dan individu tersebut menggunakan akaun palsu bagi menyembunyikan identiti sebenar. Informan 4 menjelaskan:

“...saya pernah tengok kawan saya muat naik status bukti dia diganggu dengan orang yang dia tak kenal. Dia mesej ajak kawan saya untuk buat seks. Kawan saya siasat Facebook dia, rupanya dia guna akaun palsu sebab nak tawarkan perkhidmatan seks" (Informan 4, 24 tahun).

Dapatan kajian menunjukkan bahawa, media sosial membuka ruang kepada wanita muda untuk menjadi mangsa gangguan seksual, iaitu dengan cara diajak melakukan hubungan seks. Ajakan untuk melakukan hubungan seks ini datang daripada individu yang dikenali, individu yang tidak dikenali dan individu yang menggunakan akaun palsu. Kajian membuktikan bahawa, media sosial memudahkan golongan wanita muda untuk berkenalan dengan lelaki dalam talian, dan 
sebilangan daripada mereka suka berbual dengan lelaki yang dikenali di media sosial. Tingkah laku menerima dan melayani lelaki di media sosial membuka ruang kepada wanita muda untuk terdedah kepada risiko ajakan untuk melakukan hubungan seksual. Hal ini dibuktikan melalui temu bual yang menunjukkan informan saling membalas mesej dan sering membuat panggilan video dengan pelaku.

\section{Kesimpulan}

Kecenderungan golongan wanita untuk menjadi mangsa gangguan dan jenayah siber sangat tinggi kerana mereka sangat aktif menggunakan media sosial (Greenwood et al., 2016; Madden \& Zickuhr, 2011). Golongan wanita juga suka mengambil bahagian dalam aktiviti dalam media sosial seperti memuat naik gambar, memuat naik status dan terlibat dengan urusan penjualan dan pembelian dalam talian. Aktiviti ini telah menyebabkan mereka mudah untuk menjadi mangsa jenayah siber termasuklah mangsa gangguan seksual. Situasi ini menyebabkan gangguan seksual ke atas wanita meningkat kerana penjenayah siber mudah melakukan kegiatan jenayah siber mereka melalui maklumat yang dipaparkan sendiri oleh mangsa. Media sosial turut berperanan sebagai agen penting dalam penyebaran maklumat, video dan gambar berunsur pornografi. Di samping itu, media sosial juga menjadi tempat pelaku atau pemangsa seksual untuk mencari, mengumpan dan mendapatkan mangsa untuk tujuan seks. Interaksi yang berlaku antara wanita muda dan pengguna media sosial yang berhasrat untuk menjadikan mereka mangsa seks, telah menyebabkan insiden gangguan seksual ini berlaku.

Kajian ini telah menyumbangkan pengetahuan tentang perlakuan gangguan seksual terhadap wanita muda, yang mana berlaku disebabkan oleh kerentanan wanita muda yang didasari oleh tiga faktor, iaitu faktor individu, faktor media sosial dan faktor penjenayah siber. Dari sudut faktor individu, sikap wanita muda yang senang berkongsi maklumat peribadi termasuk gambar di media sosial, memudahkan mereka disasarkan untuk menjadi mangsa. Dari sudut faktor media sosial, sifat media sosial yang menggalakkan perkongsian maklumat peribadi, termasuk foto dan lokasi keberadaan, boleh menjadikan pengguna vulnerable (rentan) iaitu mudah menjadi mangsa kepada perkara tidak diingini; dan ketiga faktor pelaku jenayah siber yang berhasrat menyasarkan wanita sebagai mangsa.

Kajian kes berkaitan gangguan seksual secara atas talian ini memberi maklumat baharu dan memperkembangkan lagi bidang ilmu kajian geografi sosial yang memberi fokus kepada jenayah seksual melalui media sosial. Kajian juga boleh menjadi garis panduan kepada pihak kerajaan dan bukan kerajaan untuk mengadakan dasar dan langkah yang sesuai bagi mengekang perilaku jenayah seksual atas talian daripada menjadi semakin parah dalam kalangan masyarakat. Untuk kajian lanjutan, artikel ini mencadangkan dua bidang kajian untuk dilakukan, iaitu mengkaji faktor kecenderungan yang menyebabkan pengguna media sosial terlibat dengan kegiatan seksual secara atas talian dan mengkaji kesan gangguan seksual dalam talian terhadap mangsa. Kedua-dua bidang kajian ini penting dilakukan bagi melihat mengapa pengguna media sosial terlibat dengan kegiatan negatif ini dan apakah kesan-kesan yang wujud kepada mereka yang pernah menjadi mangsa. Kajian lanjutan ini perlu dilakukan memandangkan pengguna media sosial semakin meningkat dan pelbagai jenis aplikasi berkaitan pornografi wujud serta berkembang seiiring dengan peredaran zaman. 


\section{Rujukan}

Ab. Halim Tamuri \& Zarin Ismail. (2009). Hubungan antara pegangan nilai moral dengan media massa: Tinjauan ke atas remaja Melayu luar bandar. Sari, 27, 119-212.

Amran Hassan \& Suriati Ghazali. (2013). Attraction and Sex Symbol of Males in the Eyes of Malaysian Male-to-Female Transsexual. International Journal of Social Science and Humanity, 3(2), 176-179.

Boone, J. (2011). Criminal Use of Social Media. National White Collar Crime. Retrieved from www.iacpsocialmedia.org/Portals/1/documents/NW3CArticle.pdf.

Collins, R. L., Martino, S. C., \& Shaw, R. (2011). Influence of New Media on Adolescent Sexual Health: Evidence and Opportunities, Working Paper WR-761. Retrieved from http://www.rand.org/pubs/working_papers/WR761.html.

Creswell, J. W. (1998). Qualitative inquiry and research design: Choosing among five traditions. Thousand Oaks, CA: Sage Publications.

Daneback, K., Cooper, A., \& Månsson, S.-A. (2005). An Internet study of cybersex participants. Archives of Sexual Behavior, 34, 321-328.

Danish Yusrie Mohd Khairul \& Mohammad Rahim Kamaluddin. (2017). Psikologi tingkah laku seks yang berbahaya dalam kalangan lelaki dewasa Malaysia yang belum berkahwin. eBangi, 14(5-Special Issue), 1-17.

Fairbairn, J. (2013). Sexual violence and social media. Retrieved from http://scholar.google.com/ scholar?as_q=Sexual+Violence+and+Social+Media.

Greenwood, S., Perrin, A., \& Duggan, M. (2016). Social Media Update 2016: Facebook usage and engagement is on the rise, while adoption of other platforms holds steady. Retrieved from http:// www.pewinternet.org/2016/11/11/social-media-update-2016/.

Guan, S. S. A., \& Subrahmanyam, K. (2009). Youth internet use: Risks and opportunities. Current Opinion in Psychiatry, 22(4), 351-356. http://doi.org/10.1097/YCO. 0b013e32832bd7e0

Haja Mydin Abdul Kuthoos, Noraida Endut, Azman Azwan Azmawati, Intan Hashimah Mohd Hashim \& Nor Hafizah Selamat. (2016). Penerokaan awal terhadap jenayah seksual dalam kalangan remaja lelaki di Malaysia: Satu kajian kes terhadap remaja di sebuah pusat pemulihan. 3rd Kanita Postgraduate International Conference on Gender Studies. Universiti Sains Malaysia.

Jain, M. R., Gupta, P., \& Anand, N. (2012). Impact of Social Networking Sites in the Changing Mindset of Youth on Social Issues - A Study of Delhi-NCR Youth. Journal of Arts, Science \& Commerce. Vol.- III, Issue 2(2), 36-43.

Khadijah Alavi, Salina Nen, Fauziah Ibrahim, Noremy Md. Akhir, Mohd Suhaimi Mohamad \& Noorhasliza Mohd Nordin. (2012). Hamil Luar Nikah dalam Kalangan Remaja. Journal of Social Sciences and Humanities. 7(1), 131-140.

Loizou, V. (2012). To What Extent has Facebook Become a Conduit for Criminal Activity?. Internet Journal of Criminology. Retrieved from https://www.academia.edu/3434608/To_what_extent_has_Facebook_become_a_conduit_ for_criminal_activity

Madden, M., \& Zickuhr, K. (2011). 65\% of online adults use social networking sites. Pew Research Center. Retrieved from https://www.pewresearch.org/internet/2011/08/ 26/65-of-onlineadults-use-social-networking-sites/. 
Maznah Ibrahim. (2014). Wanita dan Penggunaan Media Sosial. Buletin Persatuan Wanita UKM (Suaranita). Bil. 69. Retrieved from http://www.ukm.my/ sukmanita/ files/ Suaranita-Bil69.pdf.

Morse, J. M. (1994). Designing funded qualitative research. Dalam Denizin, N. K \& Lincoln, Y. S., Handbook of qualitative research (2nd Ed). Thousand Oaks, CA: Sage.

Nielsen. (2011). State of the media: the social media report. Retrieved from http://www.nielsen. com/us/en/insights/reports/2011/social-media-report-q3.html.

Norhayati Mat Ghani \& Suriati Ghazali. (2015). Tindak balas pengguna YouTube terhadap kes buli dalam kalangan remaja di Malaysia. Sains Humanika, 6(1), 9-17.

Reed, \& Angel. (2000). Computer law. Blackstone Press Limited: London.

Robinson, G. M. (1998). Methods and Techniques in Human Geography. Chichester: John Wiley \& Sons.

Shakti, S., \& Dhanoa, R. (2011). Cyber - crime awareness. International Journal in Multidisciplinary and Academic Research, 2(2), 1-7.

Suriati, G., Jabil, M.J., Azilah, M.N., Narimah, S. \& Jas Laile Suzana, J. (2012). Difusi ruangan budaya transeksualisme dan imaginasi geografi pelajar lelaki berpenapilan silang di universiti tempatan Malaysia. Journal of Social Sciences and Humanities, 7(1), 252-266.

Thelwall, M., Sud, P., \& Vis, F. (2012). Commenting on YouTube videos: From Guatemalan Rock to El Big Bang. Journal of the American Society for Information Sciences and Technology, 63(3), 616-629.

Wery, A., \& Billieux, J. (2017). Problematic cybersex: Conceptualization, assessment, and treatment. Addictive Behaviors, 64(1), 238-246.

Wolak, J., Mitchell, K., \& Finkelhor, D. (2006). Online victimization of youth, five years later. Retrieved from http://www.unh.edu/ccrc/pdf/CV138.pdf.

XiaoTong, Liu. (2018). Privacy exposure on WeChat from users' perspective: A study among the university students in China. Retrieved from http://nu.divaportal.org/smash/get/ diva2:1289642/ FULLTEXT01.pdf.

Yar, M. (2006). Cybercrime and Society. London: Sage.

Yar, M. (2012). E-Crime 2.0: the criminological landscape of new social media. Information \& Communications Technology Law, 21(3), 207-219.

Young, K.S. (2000). Profiling cybersex addiction and true online pedophilia among virtual sex offenders. Poster presented at the 108th Annual Meeting of the American Psychological Association, August 4, 2000. Washington, DC.

Zakaria Ismail, Abdul Malik Habeeb Mohd, \& Malani Achro. (2001). Gangguan seksual di tempat kerja: Definisi, kesan dan langkah mengatasinya. Dalam Wilson, F.M. (1995). Organization Behaviour and Gender. Retrieved from http://repo.uum.edu.my/449/1 /Zakaria_Ismail.pdf. 